\title{
On some postpositional elements in Danish ${ }^{1}$
}

\author{
Michael Nguyen \\ Aarhus University
}

\begin{abstract}
This paper investigates the distribution of a number of postpositional elements in Danish. The main findings are the following:

(i) Some postpositional constructions are used for abstract notions such as temporal relations rather than literal, spatial relations.

(ii) The head nouns of postpositional complements are often semantically bleached nouns such as sted 'place', vej 'street', vegne 'streets' (an archaic plural form of vej).

(iii) Some postpositional elements have the function of adding referents to or subtracting them from a set of referents.

(iv) There is not always free variation between the prepositional and postpositional construction. This is because there is often a semantic difference between the two constructions, and because the preposition and the postpositional element differ in what kinds of complement they can select.
\end{abstract}

\section{Introduction}

Given that Danish is a VO language, it is of no surprise that it is a prepositional language. There are, however, some elements which could be classified as postpositions or which have certain postpositional properties. A preposition occurs before its complement; a postposition occurs after it. In other words, postpositional and prepositional phrases presumably have the same hierarchical structure, but differ in their linearization.

1 I would like to thank Kristoffer Friis Bøegh, Yonatan Goldshtein, Henrik Jørgensen, Paul Law and Jeroen Willemsen for useful comments and discussion. Furthermore, I thank Simona Zetterberg Gjerlevsen and Ann-Katrine Schmidt Nielsen for discussing with me the semantics of some of the examples. I also thank Tavs Bjerre for providing me with a list of Danish prepositions.

Ken Ramshøj Christensen, Henrik Jørgensen \& Johanna L. Wood (eds.). 2019.

The Sign of the $V$-Papers in Honour of Sten Vikner.

Dept. of English, School of Communication \& Culture, Aarhus University, pp. 449-465, doi:10.7146/aul.348.108. (C) The author(s). 
This paper deals with elements that could be regarded as postpositions. Note I do not make the claim that they are in fact postpositions; rather my goal here is to bring some data to bear to point out that they might be analyzed as such.

In the Danish literature, only few remarks are made on postpositions. Hansen \& Heltoft (2011: 37, 437) do not examine or discuss postpositions in any greater detail (apart from whether the genitive $-s$ is an enclitic postposition). Similarly, neither Christensen \& Christensen (2009) nor Diderichsen (1976) make any mention of the term 'postpositions', although Diderichsen does mention a number of fixed constructions that involve some kind of adpositional/adverbial/particle/adjectival element following the noun (Diderichsen 1976: 228). To my knowledge, apart from scattered remarks on postpositional constructions (Falk \& Torp 1900: 313; Hansen 1967: III, 210, 213-214; Mikkelsen 1911: 370-371), no detailed description exists.

Two main aspects of these postpositional constructions will be examined. The first aspect is how productive these postpositional constructions are. This concerns the complement that can be selected by the postpositional element. ${ }^{2}$ The second aspect is whether there is free variation between the prepositional and postpositional construction. This is relevant given the assumption that all postpositional elements are formally identical to their prepositional counterparts. ${ }^{3}$ The elements I tested for postpositionhood

2 I refer to the constituent preceding the postpositional element as the complement of that element, although I do not necessarily claim that the postpositional element is indeed a postposition.

3 If one accepts this assumption, that would leave potential postpositions that do not have a prepositional counterpart out of consideration. For instance, rundt 'around' in its typical use is a verb particle and not a preposition, i.e. it has no prepositional counterpart. But in Jorden/verden rundt 'all around the world', rundt might be a postposition, taking the preceding nominal as its complement.

Some properties of rundt suggest that it could be a postposition: For instance, Jorden/verden + rundt can satisfy the requirement that bo 'live' takes an adpositional phrase, see (i) and (ii), and due to the fact that it can modify nominals, just like other adpositional phrases, see (iii):

(i) Nikolaj $[\ldots]$ bor verden rundt på Airbnb[...]

N. lives world around on Airbnb

'N. lives all around the world, using Airbnb'

(https://www.euroman.dk/kultur/nikolaj-og-hans-kareste-bor-verden-

rundt-pa-airbnb-vi-har-fundet-en-alternativ-made-at-leve-pa)

(ii) Alle mine venner bor jord-en rundt[]

All my friends live Earth-the around

'All my friends live all over the world'

(Oral data from a focus interview in Nielsen \& Kristensen 2010: 28) 
are assigned the category 'præposition' in Retskrivningsordbogen (Dansk Sprognævn 2012), the official spelling dictionary of Danish.

The data to be discussed are mainly from the Danish text corpus KorpusDK and from Google searches. In KorpusDK, I primarily used a code that searched for strings containing a noun followed by the postpositional element in question and by some punctuation character. This method is not bulletproof. On the one hand, it yielded many irrelevant results, and on the other hand, it did not extract all examples of postpositional constructions; more specifically, not all potential complement types would be extracted. Thus, various other codes were also used.

In the following, when relevant, I use the term P-ELEMENT to be neutral with respect to the categorial status of the element in question, including elements that may be particles.

\section{The data and some preliminary analysis}

\subsection{Verb particle or postposition?}

In order to render the postpositional status of a P-element plausible, cases of non-postpositional uses are to be excluded. One such case is that of verb particle constructions where the particle is formally identical to uncontroversial adpositions, such as igennem 'through':

(1) Han læste bog-en igennem.

He read book-the through

'He read through the book.'

This is a problem given that the object always precedes the particle in Danish (Diderichsen 1976: 184ff, 236ff; Vikner 2017). In order to distinguish between verb particle constructions and postpositional constructions, a number of tests may be conducted. It is important to keep in mind that the

(iii) Flygtningestrømme verden rundt taler deres barske sprog Refugee.waves world around speak their harsh language om en misbrugt frihed [...].

about a misused freedom

'Refugee waves all over the world tell their own tale about a misused freedom [...].'

(KorpusDK)

Moreover, Jorden/verden can be regarded as the Ground element, which is crosslinguistically realized as the complement of the adposition (Svenonius 2007). If the above considerations are on the right track, Jorden/verden rundt is possibly a postpositional phrase. 
tests may falsify or render either structure more probable, but logically, the falsification of either structure does not imply that the other is present.

One way of distinguishing particles and postpositions would be to interpolate some element between the nominal and the P-element (without fronting the nominal). In verb particle constructions, manner adverbials may intervene between the nominal and the particle, as pointed out in recent works couched in the Diderichsen tradition in Danish linguistics (Heltoft 1992: 33-35 and Jørgensen 2014: 98-99). For instance, $u d$ is uncontroversially a particle, and an adverbial may therefore intervene between the nominal and the particle:

(2) Han smed Peter hurtigt ud.

He threw $P$. quickly out

'He quickly threw P. out.'

Assuming that postpositions do not strand without fronting of the complement, parallel to preposition stranding, nothing can intervene between the complement and the postposition. If the test of inserting an adverbial yields a grammatical result, the P-element in question is most likely not a postposition. Thus, igennem in (1) is most likely not a postposition:

(3) Han læste bog-en hurtigt igennem.

He read book-the quickly through

'He quickly read through the book.'

Contrast this with (4), where an adverbial cannot intervene:

(4) * Hun sov hele forestilling-en tungt igennem. She slept whole play-the deeply through

'She slept deeply through the whole play.'

This indicates that igennem is plausibly not a verb particle in (4).

Another way of distinguishing particles and adpositions is to test for constituency. It is well-known that a preposition and its complement conform to constituency tests, whereas the object and the particle do not (Svenonius 2003). Assuming that prepositions and postpositions behave alike, the topicalization test in (5) and (6) indicates that igennem in (1) and (5) is not a postposition, whereas it is not a particle in (4) and (6). 
(5) * Bog-en igennem læste han.

Book-the through read he

(6)

$\begin{array}{lllll}\text { Hele forestilling-en } & \text { igennem } & \text { sov } & \text { hun. } \\ \text { Whole } & \text { play-the } & \text { through } & \text { slept } & \text { she }\end{array}$

It is, however, not always a trivial matter to distinguish verb particles from postpositions. ${ }^{4}$ In this paper, we will see both more convincing as well as doubtful cases of what seem to be postpositions.

\subsection{Postpositional P-elements and their distribution}

In this subsection I show the distribution of a number of P-elements that exhibit postpositional properties. The following division of P-elements is based on their formal properties, i.e. being prefixed with an $i$ - (Section 2.2.1), as well as their semantics, i.e. adding or subtracting one or more referents to/from a set of referents (Section 2.2.2). Moreover, a group of P-elements do not belong to either of those groups (Section 2.2.3).

\subsubsection{I-prefixed P-elements}

In Nguyen (2019), I discuss a group of P-elements that are nearsynonymous, at least when used as prepositions. They can be divided into $i$-prefixed P-elements and non- $i$-prefixed elements: ${ }^{5}$

\begin{tabular}{|l|l|}
\hline Non- $i$-prefixed P-elements & $i$-prefixed P-elements \\
\hline Blandt 'among' & Iblandt 'among' \\
\hline Gennem 'through' & Igennem 'through' \\
\hline Mellem 'between'/'among' & Imellem 'between'/'among' \\
\hline Mod 'toward'/'against' & Imod 'toward'/'against' \\
\hline
\end{tabular}

4 In particular, the P-elements ncer 'near' and foruden 'without' are difficult to analyze, and I have to leave them out of the discussion. Likewise, the P-element inklusive 'including' is not discussed either. When it follows a pronoun, the pronoun can either be in the Nominative or the Oblique case. In the KorpusDK data, it seems that the Nominative case is used when the pronoun is linked to the subject, whereas the Oblique case can be used when the pronoun is linked to any syntactic function.

5 The $i$-prefixed P-elements seem to be the result of univerbation processes, i.e. the diachronic formation of one element out of more elements. Thus, diachronically, these P-elements (maybe except for igennem) consist of a preposition $i$ plus one or more elements, see Den Danske Ordbog 'The Danish Dictionary'. 
The members of both groups can be used prepositionally, but only the $i$-prefixed P-elements can be used postpositionally (see also Hansen 1967, III: 213-214), although I found no convincing cases of postpositional uses of iblandt and imod.

\subsubsection{Igennem 'through'}

The complement of postpositional igennem is mostly headed by nouns which denote a time span or have a duration (as noted by Falk \& Torp 1900: 313). For instance, a book has a duration in the sense that it has a plot with a certain time frame, see (7), and a night lasts an unspecified number of hours, see (8), etc. The complement also often contains the adjective hele 'whole', as in (9).

(7) [...] havde han ikke ladet hende optræde, som hun gør had he not let her appear as she does hele bog-en igennem. whole book-the through '... would he not have let her appear, as she does all the way through the book.'

(8) [...] ved at opholde sig i samme seng en nat igennem. by to stay REFL in same bed a night through 'by staying in the same bed throughout a whole night.'

(9) $[\ldots]$ at selskab-et $[\ldots]$ giver os ret hele vej-en igennem. that company-the [...] give us right whole street-the through 'that the company agrees with us all the way through.' (i.e. 'throughout all this time')

(10) [...] mange nye fisk, der vil stå ind fra many new fish that will stand in from Østersøen sommer-en igennem.

The.North.Sea summer-the through 'many new fish that will come in from The North Sea throughout the summer.' 
In (9), vejen 'the street' indicates a time span or a process, throughout which the given event takes place. It is only when vejen precedes igennem that it is used in this way. If vejen follows igennem, it cannot mean 'process' or denote a time span. It can only mean 'street':

(11) $\# / *$ Hun kede-de sig igennem hele vej-en She bore-PAST REFL through whole street-the

Intended: 'She was bored all the way through/throughout the whole time.'

The prepositional counterparts of (8) and (10) are slightly degraded, whereas the prepositional counterpart of (7) is grammatical (it is not clear to me whether there is a semantic difference between (7) and (14)):

(12) ? [...] ved at opholde sig i samme seng igennem en nat. by to stay REFL in same bed through a night 'by staying in the same bed throughout a whole night.'

(13) ? [...] mange nye fisk, der vil stå ind fra many new fish that will stand in from Østersøen igennem sommer-en.

The.North.Sea through summer-the 'many new fish that will come in from The North Sea throughout the summer.'

(14) [...] havde han ikke ladet hende optræde, som hun gør had he not let her appear as she does igennem hele bog-en. through whole book-the

(Compare (12) to (8), (13) to (10) and (14) to (7).) In any case, there is not always free variation between the prepositional and postpositional construction.

\subsubsection{Imellem 'among'/'between'}

The complement of postpositional imellem can be realized as a regular nominal (15) as well as a pronoun (16) (the latter cannot be the complement of postpositional igennem): 
(15) [...] det kommende økonomiske samarbejde, DDR the upcoming economic cooperation East.Germany og Vesttyskland imellem. and West.Germany between

'the upcoming economic cooperation between East Germany and West Germany.'

(16) $[\ldots]$ at følge embedsmænd-ene-s forklaringer og

to follow officials-the.PL-GEN explanations and

de modsigelser, som kommer til udtryk dem imellem. the contradictions that come to expression them between 'to follow the officials' explanations and the contradictions that come to light between them.'

(KorpusDK)

Both (15) and (16) allow for prepositional use of imellem:

(17) $[\ldots]$ det kommende økonomiske samarbejde DDR the upcoming economic cooperation East.Germany og Vesttyskland imellem. and West.Germany between

'the upcoming economic cooperation between East Germany and West Germany.'

[...] at følge embedsmændenes forklaringer og de to follow officials-the.PL-GEN explanations and the modsigelser, som kommer til udtryk imellem dem. contradictions that come to expression between them 'to follow the officials' explanations and the contradictions that come to light between them.'

Imellem in its prepositional use means either 'among' or 'between', in which case it can denote either a spatial or an abstract relation between a number of referents. The postpositional construction of imellem, however, can typically only denote some kind of personal relationship between the referents. In this case, imellem takes animate referents as its complement, metonymic extensions included. Thus, inanimate referents, such as trees, cannot be realized as the complement of postpositional imellem (unless the trees are endowed with some sort of animacy): 
(19)

* træer-ne imellem trees-the between/among

'among/between the trees'

(20) imellem træer-ne

between trees-the

'between the trees'

The asymmetry in semantics between the prepositional and postpositional constructions means that they are not interchangeable.

\subsubsection{P-elements which add or subtract referents}

The common denominator of this category of postpositional P-elements is that they presuppose a set of referents. These P-elements add referents to or subtract them from this set. This should become clear in the following.

\subsubsection{Fraset 'except for'}

I found one postpositional example of fraset, which is the perfect participle form of the archaic verb frase. In this example, fraset excludes the genre kirkemusikken 'the church music' from a set of music genres:

(21) $[\ldots]$ den myreflittige [...] komponist, the hardworking componist

der skrev i alle genrer, kirkemusikk-en fraset.

that wrote in all genres, church.music-the except.for 'the hardworking componist who wrote in all genres, except for the church music genre.'

(KorpusDK)

Prepositional fraset can take nominals (22) as well as clauses (23). Postpositional fraset can only take nominals, see (21) above, but not clauses, see (24) below.

(22) Alle,

fraset professionelle syltetøj-s-fabrikanter, Everybody, except.for professional jam-LINK-manufacturers kan således deltage. can therefore participate

'Everybody, except for professional jam manufactures, can therefore participate.' 
(23) Men fraset, at de nærmeste medarbejdere kun har But except.for that the closest co-workers only have positivt at sige om den 58-årige $\quad[\ldots] \quad$ er der [...] positive to say about the 58.year.old is there 'But disregarding the fact that the closest co-workers only have positive things to say about the 58 -year old, there is ...'

((22) and (23) are from KorpusDK)

(24) * Men at de nærmeste medarbejdere kun har positivt But that the closest co-workers only have positive at sige om den 58-årige [...] fraset er der [...] to say about the 58.year.old except.for is there Intended: 'But disregarding the fact that the closest co-workers only have positive things to say about the 58 -year old, there is ...'

\subsubsection{Med 'with'/'including'}

Med 'with'/'including' can take nominals when used postpositionally, and the whole construction, which is quite archaic, is almost always prefaced with $o g$ 'and':

(25) Og Herren-s ild [... fortærer ikke blot ofr-et, And Lord-GEN fire consumes not just offering-the men altr-et med.

but altar-the including

'And the fire of the Lord not only consumes the offering, but the altar too.'

(26) [...] hold øje med døtre-ne, ja og vor hustru med. keep eye with daughters-the, yes, and our wives including 'keep an eye on the daughters, yes, and keep an eye on our wives as well.'

(KorpusDK)

Note that an elliptical analysis in which med takes a deleted complement is not tenable. This is because the non-elided source is difficult to reconstruct without a change of meaning. In (27), the alleged deleted complement is realized overtly: 
(27) \# Hold øje med vor hustru med døtre-ne / dem. Keep eye on our wife with daughters-the / them 'Keep an eye on our wife with the daughters/them.'

The difference between (25) and (27) is that in (25), it is vor hustru that is added as a referent, whereas it is døtrene or dem that is added in (27). The fact that it is hard to reconstruct a well-formed non-elided source renders the elliptical analysis less plausible.

With respect to med in its prepositional use, it usually means 'with', e.g. Jeg danser med ham 'I am dancing with him'. This does not correspond to its meaning when used postpositionally. Thus, the prepositional and postpositional construction are not interchangeable, compare (25) and (28):

(28) \#/* Og Herren-s ild $[\ldots]$ fortærer ikke blot ofr-et,
And Lord-GEN fire consumes not just offering-the
men med altr-et.
but with altar-the

Intended: 'And the fire of the Lord not only consumes the offering, but the altar too.'

\subsubsection{Undtaget 'except for'}

Undtagen 'except for', but not undtaget, is categorized as a preposition in Retskrivningsordbogen. One difference between undtagen and undtaget is that the former is identical to the supine form of the verb undtage 'except', whereas the latter is identical to the perfect participle. Assuming that undtagen is correctly classified as a preposition, there is no a priori reason why undtaget cannot be an adposition.

I found some postpositional instances of only undtaget, not of undtagen. Two of these are given below:

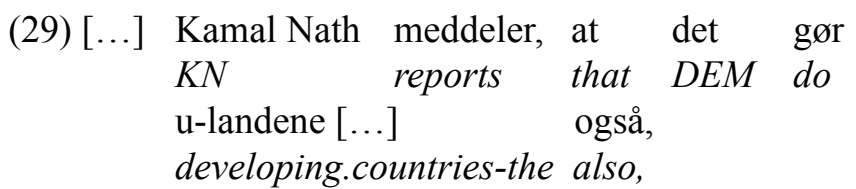

$\begin{array}{llll}\text { de to nævnte u-lande } & \text { undtaget. } \\ \text { the two mentioned developing.countries-the except.for. }\end{array}$

' $\mathrm{KN}$ informs that so do the developing countries, except for the two mentioned developing countries.' 
(30) Der er totalt konsensus (mig undtaget)om, at [...] There is total consensus me except.for PREP that

'There is a consensus (which does not include me) that ...' (http://mitsaakaldtlesbiskeliv.dk/author/admin/page/14/)

Again, an elliptical analysis is not plausible, for the same reasons as for med. It is difficult to reconstruct the unelided source; see the attempts of reconstructing the non-elided source of mig undtaget in (30):

(31) * Mig blev undtaget.

Me was exempted

Intended: 'I was exempted.'

(32) Jeg er undtaget.

I am exempted

'I was/have been exempted.'

$\begin{array}{llllll}\text { (33) \# } & \text { Nogen } & \text { har undtaget mig fra } & \text { konsensus. } \\ & \text { Somebody has exempted me from consensus }\end{array}$

In (31), the alleged unelided source is ungrammatical. In (32), the pronoun is not in the same case as in (30). As for (33), the both the meaning and the word order deviate from that of (30): Semantically an action is implied in (33), whereas no action is implied in (30). In terms of word order, the pronoun precedes undtaget in (30) but follows it in (33). For these reasons, an ellipsis analysis is less plausible.

Undtaget can also be used prepositionally, but there does not seem to be any semantic difference between the prepositional and postpositional construction. When used prepositionally, it can take prepositional phrases as complements in addition to nominals:

Alle var fyret [...], undtaget fire mand [...].

Everybody was fired, except.for four man

'Everybody was fired, except for four men.'

(35) Overalt blev jeg berørt, undtaget i mit skød. Everywhere was I touched, except.for in my lap 'I was being touched everywhere, apart from in my lap.'

(KorpusDK) 
One difference between undtaget and fra-set, diachronically 'from-seen', is that the verbs from which they are formed, are not equally productive: The verb undtage 'exempt' is still in use, whereas the verb frase 'disregard' is no longer in use. One could imagine undtage( $n)$ developing in the same direction as frase to be devoid of verbal content.

It is an open question whether the constructions involving undtaget and fraset are postpositional phrases or absolute participial constructions. First, Kobayashi (2012: 25-28) argues that verbs, and thus participles, do not have to be present in English absolute constructions. This leaves open the option of analyzing all constructions involving P-elements in this section as absolute constructions. Second, Kobayashi rejects both the postpositional phrase analysis and the absolute analysis. Here I take no stance on this question.

\subsubsection{Other P-elements}

\subsubsection{Fra 'from'}

Postpositional fra is used with sted 'place', vegne 'streets' and vej 'street', where vegne is an archaic plural form of vej: ${ }^{6}$

(36) Der lugter af mad et eller andet sted fra. EXPL smells of food one or another place from

'There is a smell of food coming from somewhere.'

$\begin{array}{llllll}\text { [...] der er } & \text { bud efter hende alle vegne fra. } \\ \text { there be.PRES call after her all streets from }\end{array}$

'There are many people who want to contact her.'

$\begin{array}{llllll}\text { Lige da hun var trådt ind af dør-en, } & \text { ind } \\ \text { Right when she was stepped into of door-the, } \\ \text { kom overlæge-n } & & \text { styrtende den anden vej fra. }\end{array}$
came chief.surgeon-the running the other way from 'Just as she came inside by the door, the chief surgeon came from the other direction.'

((36)-(38) are from KorpusDK)

There seems to be a slight meaning difference between the prepositional and postpositional use. Compare the translations of (36) and (39):

6 Interestingly, these nouns can be used in nominal adverbials without being introduced by prepositions (Larson 1985; Nguyen 2018). In English, such an instance would be $\mathrm{He}$ went that way. 
(39) ? Der lugter af mad fra et eller andet sted.

'there is a smell of food coming from some other place (than this place).'

Focusing on the P-complement headed by sted, it is indefinite in (36) and (39). If it is definite, the complement can most often only follow fra:

$\begin{array}{cllll}\text { (40) * Jeg kommer det } & \text { smukkeste } & \text { sted } & \text { fra } \\ \text { I come the } & \text { most.beautiful place } & \text { from }\end{array}$

(41) Jeg kommer fra det smukkeste sted.

'I am from the most beautiful place.'

\subsubsection{Over 'over'/'throughout'/'all over'}

Postpositional over is primarily used with various time units, e.g. sommeren/vinteren over 'throughout the summer/winter', weekenden over 'throughout the weekend', julen/påsken over 'throughout Christmas/ Easter' and natten over 'overnight'. It is also used in kloden over 'all over the world' and its synonymous variants verden/Jorden over. See examples below:

[...] tunneler, der er bygget klod-en
tunnels that are built world-the
throughout
'tunnels that are built all over the world.'

(43) Læg et stykke klipfisk [...] i vand natt-en over. Put a piece clipfish in water night-the over 'Put a piece of clipfish into some water, and leave it overnight.'

(44) $[\ldots]$ og så ligger sne-en jo jul-en over. and then lies snow-the PART Christmas-the over 'and then the snow will stay over the course of the Christmas days.'

(KorpusDK)

In the postpositional construction, the given event takes place throughout the whole given time span, see (45). This is not implied in the prepositional construction (46):

$\begin{array}{llll}\text { Han var hjemme } & \text { jul-en } & \text { over. } \\ \text { He was } & \text { home } & \text { Christmas-the } & \text { over }\end{array}$

'He was at home for the whole Christmas time.' 
(46) Han var hjemme over jul-en.

'He was at some point home during Christmas time.' (not necessarily for the whole Christmas time)

Julen over presupposes an event that takes place over the whole given period of time, whereas over julen does not presuppose this. In this light, it is of no surprise that postpositional igennem 'through' (Section 2.2.1.1) is often combined with a complement containing the element hele 'whole', since the postpositional construction presupposes that the given event lasts throughout the whole denoted time span.

The semantic contrast between the prepositional and the postpositional construction seems to be similar to that of adverbials such as hele mandagen 'all day Monday' and om mandagen 'on Monday', where the former presupposes that the given event takes place throughout Monday, and the latter presupposes that the event takes place on Monday:

Han var hjemme hele mandag-en.
He was home

'He was at home all day Monday.'

$\begin{array}{llll}\text { Han } & \text { var hjemme } & \text { om } & \text { mandag-en. } \\ \text { He was } & \text { home } & \text { on } & \text { Monday-the }\end{array}$

'He was at home on Monday.' (not necessarily for the whole day)

Note that the same semantic notion also applies to spatial relations, e.g. Jorden over, which means something like 'all over the world': Whatever is predicated applies to the whole world.

\section{Summary}

I have examined a number of elements which could be regarded as postpositions. The following patterns can be observed:

i. In some cases, the postpositional constructions are used for abstract notions such as temporal relations rather than spatial relations.

ii. The head noun of the postpositional complement is often semantically bleached nouns such as sted, vej, vegne (an archaic plural form of vej).

iii. The postpositional elements med, fraset and undtaget have the function of adding referents or subtracting them from a set of referents.

iv. There is not always free variation between the prepositional and postpositional construction. This is because there is a semantic difference 
between the two constructions and because the P-element selects different types of complements, depending on its position.

The last point raises the question whether the differences between preand postpositional use is related to similar phenomena, such as that of attributive adjectives in Romance languages, where the meaning depends on the order of the adjective and the noun.

\section{References}

Christensen, Robert Zola \& Lisa Christensen. 2009. Dansk grammatik [Danish grammar], 2nd edn. Odense: Syddansk Universitetsforlag.

Dansk Sprognævn. 2012. Retskrivningsordbogen [The spelling dictionary], 4th edn. Copenhagen: Alinea.

Diderichsen, Paul. 1976. Elementcer dansk grammatik [Elementary Danish grammar]. 3rd edn. Copenhagen: Gyldendal.

Falk, Hjalmar \& Alf Torp. 1900. Dansk-norskens syntax $i$ historisk fremstilling [A historical account of Danish-Norwegian syntax]. Kristiania: H. Aschehoug.

Hansen, Aage. 1967. Moderne dansk: I-III [Modern Danish: I-III]. Copenhagen: Grafisk Forlag.

Hansen, Erik \& Lars Heltoft. 2011. Grammatik over det danske sprog [Grammar of the Danish language]. Copenhagen: Syddansk Universitetsforlag.

Heltoft, Lars. 1992. The topology of verb second and SVO languages. A study in the sign functions of word order. In Michael Herslund (ed.): Word order. Two studies on central issues in the syntax of Danish and French (Copenhagen Studies in Language 15), 13-64. Copenhagen: Handelshøjskolens Forlag.

Jørgensen, Henrik. 2014. Adverbiernes rækkefølge i henhold til Mikkelsen [The order of the adverbs with reference to Mikkelsen]. In Ole Togeby, Sten Vikner \& Henrik Jørgensen (eds.), Problemer og perspektiver $i$ dansk syntaks [Problems and perspectives in Danish syntax], 90-115. Copenhagen: Syddansk Universitetsforlag.

Kobayashi, Akiko. 2012. Postpositions in English. http://www.ipc.shimane-u.ac.jp/eigogaku/pdf_kobayashi/publications/postPs English_2012.pdf (17 August, 2019).

Larson, Richard K. 1985. Bare-NP adverbs. Linguistic Inquiry 16(4). 595-621.

Mikkelsen, Kristian. 1911. Dansk Ordföjningslaere med sproghistoriske Tillaeg. Håndbog for Viderekomne og Loerere [Danish syntax with language historical additions. Handbook for advanced readers and teachers]. Copenhagen: Lehmann \& Stages Forlag. 
Nguyen, Michael. 2018. On Danish Bare Nominal Adjuncts - a reply to Barrie and Yoo (2017). ICLLS 2018. Fourth International Conference on Linguistics and Language Studies, 143-157. Hong Kong: Chartered Institute of Linguists Hong Kong Society, School of General Education and Languages of the Technological and Higher Education Institute of Hong Kong, the Department of English Language and Literature of Hong Kong Shue Yan University, School of Humanities and Languages of the Caritas Institute of Higher Education, and School of Education and Languages of the Open University of Hong Kong. http://docs.wixstatic.com/ugd/2b7f97_12e298eb8c21496eba8c2c05fcf02cc3. pdf (24 August, 2018).

Nguyen, Michael. 2019. Extraction of R-pronouns via an intermediate position within the prepositional domain. Snippets (35). 10-12. doi:http://dx.doi.org/10.7358/snip-2019-035-nguy.

Svenonius, Peter. 2003. Swedish particles and directional prepositions. In LarsOlof Delsing, Cecilia Falk, Gunlög Josefsson \& Halldór Ármann Sigurðsson (eds.), Grammar in Focus: Festschrift for Christer Platzack, 343-351. Lund: Wallin \& Dalholm.

Vikner, Sten. 2017. Germanic verb particle variation. In Enoch O. Aboh, Eric Haeberli, Genoveva Puskás \& Manuela Schönenberger (eds.), Elements of comparative syntax: Theory and description, 371-397. Berlin: Mouton de Gruyter. https://doi.org/10.1515/9781501504037-014.

\section{Primary data, corpora and dictionaries}

https://www.euroman.dk/kultur/nikolaj-og-hans-kareste-bor-verden-rundt-paairbnb-vi-har-fundet-en-alternativ-made-at-leve-pa (21 August, 2019).

http://mitsaakaldtlesbiskeliv.dk/author/admin/page/14/ (28 February, 2019).

Den Danske Ordbog: https://ordnet.dk/ddo/forside.

KorpusDK: https://ordnet.dk/korpusdk.

Nielsen, Mathilde H. \& Nadia K. Kristensen. 2010. Personlig branding gennem sociale medier. Copenhagen: Copenhagen Business School MA thesis. https:// studenttheses.cbs.dk/bitstream/handle/10417/1011/matilde_heinz_nielsen_og nadia_kim_kristensen.pdf (26 July, 2019). 